\title{
Aspects of the Ecology of the Grass Mat Finfish Community of Kugbo Creek in Niger Delta, Nigeria.
}

\author{
$*^{1}$ Edoghotu, A. J. and ${ }^{2}$ I. A. Hart \\ ${ }^{1}$ Department of Biology, Ignatius Ajuru University of Education, Rumuolumeni, Port Harcourt. Email: \\ ${ }^{2}$ Department of Animal and Environmental Biology, University of Port Harcourt.
}

\begin{abstract}
A study on the grass-mat finfish community of Kugbo Creek was done in 3 zones of Kugbo Creek for 24 months. Biweekly samples obtained from the zones showed a total of 3192 individual finfish belonging to 26 species and 14 families. Occurrence among zones was 25 species were found in freshwater zone 1, 24 in fresh/brackish water zone 2 and 4 species in brackish water zone 3 respectively. The dominant finfish species was Dormitator pleurops with 451 individuals. The habit host rear species of Nannocharax niloticus, Karibia karibensis, Thysia ansorgii, Marcrousenius thuysi and Mastacablus loennbergi. Juveniles of Calamoichthys calabaricus, Heterotis niloticus, Channa obscura, Polycentropsis abreviata, Heterobranchus longifilis and Mastaceblus loennbergi, were also caught in the habit. This shows that some fish undergo part of their developmental stages in the grass mat habitat, including some with high commercial values. Some species such as Gymnacus niloticus and Hepsetus odoe build their spawning nest in the grass mat where they lay eggs during breeding season. Virtually all other fresh water fish species also visit the habitat either in search of food or shelter at one time or the other as most stomach content compositions are also found in the grass mat habitat, e.g. Papyranocranus afar and Xenomystus nigri, . The habitat sheltered endangered finfish species such as Neolebias powelli, that was caught during sampling. These suggest the importance and sensitive nature of the habitat and should therefore be protected.
\end{abstract}

Keywords: Grass mat, Kugbo Creek, Niger Delta, Biodiversity, Physico-chemistry and Anthropogenic Activities

The Niger Delta region of Nigeria is one of the richest environments which ecosystems are endowed with diverse natural resources and rich biodiversity. In recent times, with the advent of industrialization, most of the biodiversity in the region are quickly disappearing. Aquatic systems and habitats are dying due to inadequate caution and lack of policies that could perfect them. The situation seems worse in freshwater where less study have been done to ascertain their conditions. Anthropogenic wastes of both individuals and industries drain through these systems to their final destinations, thereby impacting or completely devastating the biota they come in contact with in the flow process. One of such habitat is the freshwater grass mat, a composition of hydrophytes that extend from the banks towards the middle of water bodies or cover the entire water surface. Often, emphases are laid on protecting mangrove habitats of marine and brackish water habitats, neglecting the grass mat of freshwater habitat. Hence, the lamentation of the Minister of Environment in the $20^{\text {th }}$ Annual Conference of the Nigerian Environmental Society "our rivers are dying" (verbal communication). This has necessitated this study.

Several aquatic habitats have been studied by several authors in the Niger Delta and suggestions made on how to protect these habitats. Emphasis had been on protecting very sensitive habitats such as mangrove swamps which are breading grounds and shelter for some fish species (Anderson I. 2005; Nwilo et.al., 2007 and World Wildlife Fund, 2006).

But none so far had been done on freshwater grass mat habitat, another very sensitive habitat shelters and serve as feeding, breading ground and shelter to several fish species and other freshwater organisms. This paper therefore attempts to unravel aspects of the ecology and importance of grass mat habitat of Kugbo Creek system in the Niger Delta. 


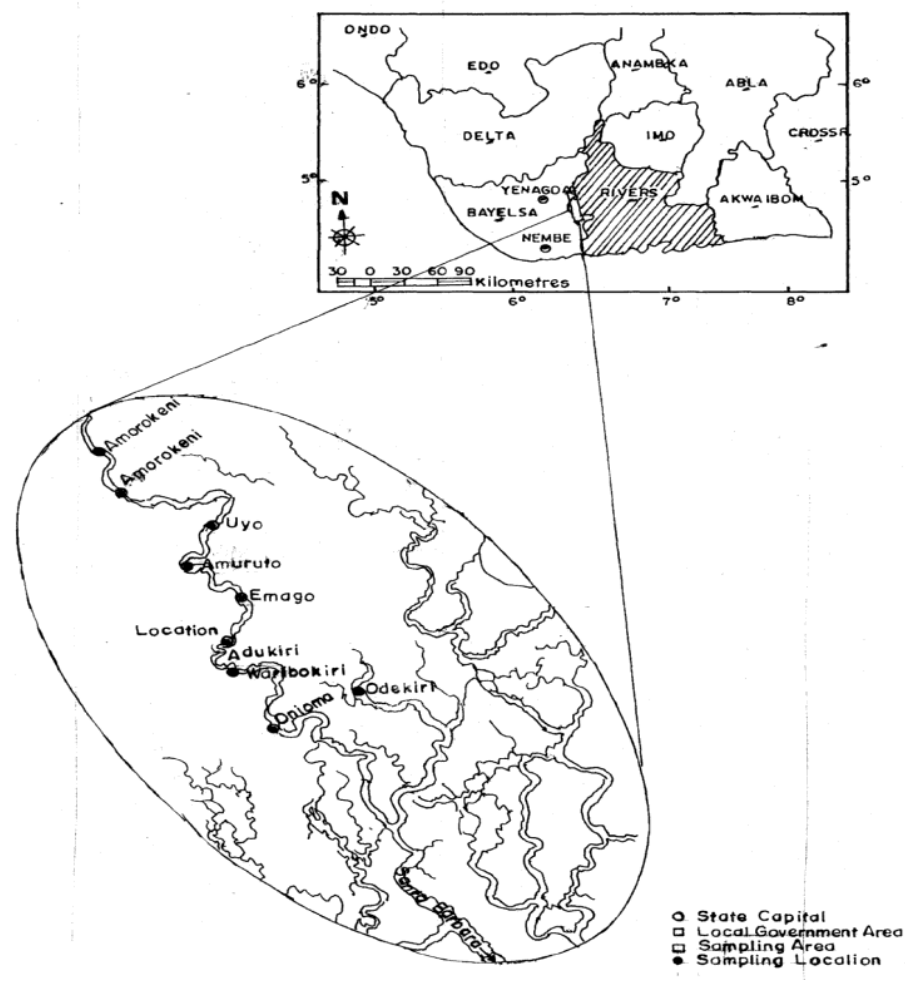

Plate 1: Map of Niger Delta, showing Rivers State and the Study Area of Kugbo Creek

\section{Study Area:}

\section{Materials and Methods}

Kugbo Creek (Latitude $4^{\circ} 40^{\prime} \mathrm{N}, 4^{\circ} 49$ and Longitude $6^{\circ} 20^{\prime} \mathrm{E}, 6^{\circ} 35 \mathrm{E}$ ) is about $175 \mathrm{~km}$ in length (nautical miles). Its width ranged from $22 \mathrm{~m}$ near source to $91 \mathrm{~m}$, downstream at the brackish region. Its freshwater stretch is about $105 \mathrm{~km}$ with grass mat area cover of about $150 \mathrm{~km}^{2}$. The Creek is linked to River Nun upstream but empties into Santa Barbara River via its estuary downstream.

The study area was divided into 3 zones and each bearing 3 sampling stations. Zone one (freshwater or Oligohaline), zone two (freshwater with brackish water inundation during day season), while zone three (brackish water with freshwater inundation during wet season). At intervals were adjoining swamps and streams that also serve as breading grounds for some species. At the brackish end, the river was tidal all year round while it was non tidal at the freshwater end during wet season or flood period.

Aquatic vegetations of the freshwater zone were predominantly Typha sp, many grasses, Elephant grass, Ipomia aquatica, Pistia stratiot, Eichornia crassipes, Azolla sp, Nympheae sp, other water lilies, and Ceratophyllum sp entangled with algae such as Spirogyra sps.

Zone two bears few halophytes, such as Acrosticum aureum, Rhizophora recemosa and Pandonus candilebium, while freshwater forms include Eichornia crassipes, Nympheae sp and Ceratophyllum sp entangled with algae (Spirogyra sps).

Zone three had predominantly Rhizophora sps., Pandonus candilebium and few fresh water forms of Eichonium crassipes, Aziola sp and elephant grass that drifted from grass mat of zones 1 and 2.

\section{Sampling Procedure}

Physical and chemical parameters were determined following international acceptable methods of American Public Health Association, APHA (1976).

Temperature was measured in situ with mercury-in-bulb thermometer and rounded off to the nearest $0.1^{\circ} \mathrm{C}$.

Depth profile of the Creek for each station was taken with a marine rope graduated at $0.5 \mathrm{~m}$ intervals, tied to a weight that served as sink. Both rope and sink were lowered into the water body and the final water level on rope marked after the sink had just arrived the bottom. The total of $0.5 \mathrm{~m}$ and fraction (if there was any), submerged in the water was taken as the depth of the creek at that point.

The Creek flow rate was obtained by: 
Flow rate $=\left(\begin{array}{c}D_{i} / t \\ \end{array}\right)$

Where;

$\mathrm{D}=$ distance of one meter rule through which a cork is made to float through

$\mathrm{t}=$ time in seconds taken for cork to float through $\mathrm{D}$.

Transparency was determined with a secchi disc and a chord graduated at one meter interval fastened to it. Fractions of $1 \mathrm{~m}$ were determined with a $30 \mathrm{~cm}$ rule and rounded off to the nearest centimeter.

$\mathrm{pH}$ levels in the three zones were determined with automated $\mathrm{pH}$ meter (Horiba, model U-10).

Dissolved Oxygen (DO) samples were collected and analyzed following the azide- modification of Winkler's method as contained in APHA (1976).

Grass mats were sampled with a pond net of $1 \mathrm{~mm}$ mesh size to obtain resident finfish fauna. Samples obtained were preserved in $10 \%$ formal saline solution and were taken to the laboratory for sorting, identification and enumeration.

Both Margelef (Van de Brock, 1979) and species richness index where used for statistical analysis.

\section{Results}

Data on results data on the grass mat finfish community of Kugbo Creek is here presented in figure 1 6 and Table 1. Temperature varied between $25^{\circ} \mathrm{C}$ and $34^{\circ} \mathrm{C}$ throughout the study period. Maximum temperature of $34^{\circ} \mathrm{C}$ was in the dry season, i.e. early August to October in freshwater zone. Similarly, mean values per station ranged from $25.6^{\circ} \mathrm{C}+1.1$ to $30.8^{\circ} \mathrm{C}+2.5$. Temperature was generally low in the wet months and relatively high in dry months during the study period.

Depth profile was observed to be higher in wet months than dry. The variation reflected among the stations. Maximum stations' depth along the creek was $925 \mathrm{~cm}$ in zone 3 in early February and minimum $(56 \mathrm{~cm}$ in station 4 during late April sampling. Mean depth ranged from $110 \mathrm{~cm}+11.3$ to $479 \mathrm{~cm}+160$.

Flow rate in the 3 zones varied throughout the period of study. Values ranged between $2.5 \mathrm{~cm} / \mathrm{s}$ to $15 \mathrm{~cm} / \mathrm{s}$. Similarly, mean values ranged from $4.3 \mathrm{~cm} / \mathrm{s}+0.7$ to $7.6 \mathrm{~cm} / \mathrm{s}+3.4$.

Secchi disc measurements values for transparency also varied widely relative to others. Values ranged from $25 \mathrm{~cm}$ to $900 \mathrm{~cm}$. Data showed increase in valued from fresh towards brackish water. Mean values ranged from $34.89 \mathrm{~cm}+2.67$ to $265.00 \mathrm{~cm}+58.87$.

$\mathrm{pH}$ values were low and ranged from 5.0 to 7.5 . Mean value was $8.9+1.3$ to $12.7+0.4$ during the sampling period.

Dissolved Oxygen (DO) values ranged between $1.7 \mathrm{mg} / \mathrm{l}$ and $13.0 \mathrm{mg} / \mathrm{l}$ while the mean values ranged from $2.9 \mathrm{mg} / \mathrm{l}+0.84$ to $8.2 \mathrm{mg} / \mathrm{l}+4.1$.

The grass mat finfish species were represented by a total of 3192 individual 26 species that belonged to 14 families. The total landing was a mixture of adults and juvenile forms. Their individual biomass ranged from $0.5 \mathrm{~g}$ to $35 \mathrm{~g}$ and length range of $1 \mathrm{~cm}$ to $8 \mathrm{~cm}$. Pick landing was in early dry season i.e. within the months of December and January and minimum landing was in wet season. Number caught throughout the period of the study varied between 12 individuals per $1,257.1 \mathrm{~cm}^{2}$ in the wet season to $1,257.1 \mathrm{~cm}^{2}$ in dry 
a)

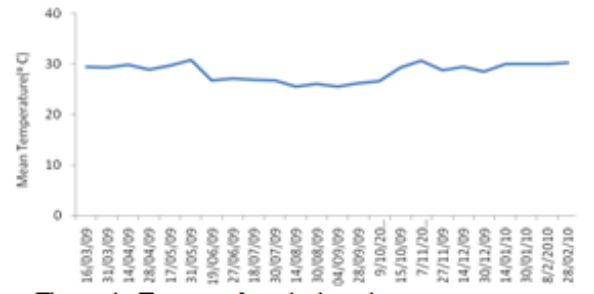

b)

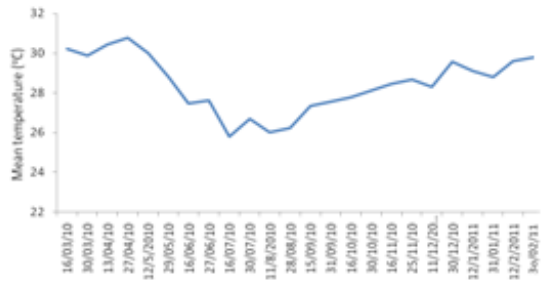

Figure 1: Temporal variations in mean temperature $\left({ }^{\circ} \mathrm{C}\right)$ of Kugbo Creek during March 2009- February 2011.

a)

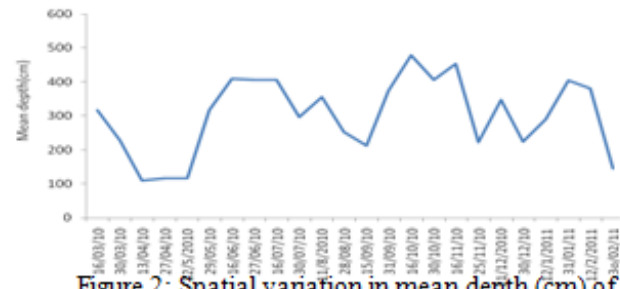

b)

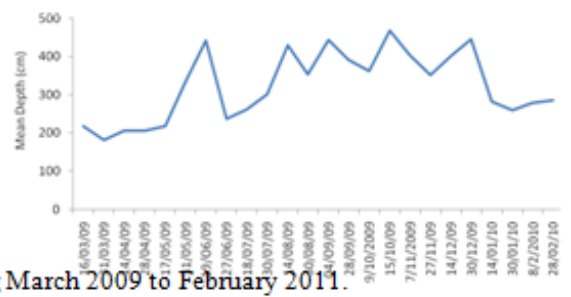

a)

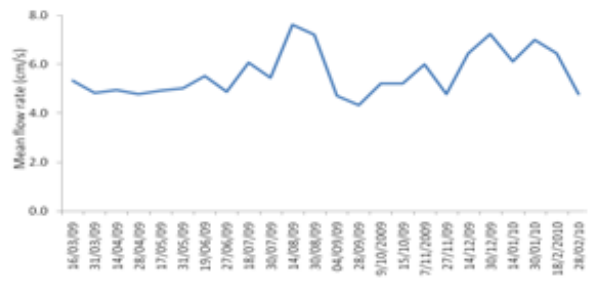

b)

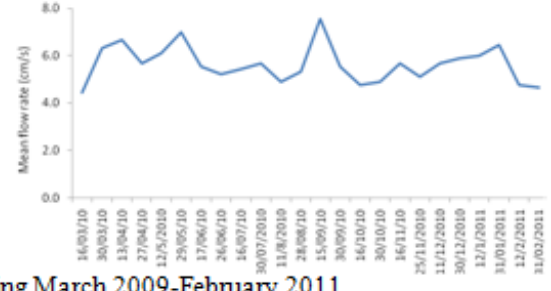

Figure 3: Spatial variations in mean flow rate (cm/s) of Kugbo Creek during March 2009-February 2011.

months. Larger forms pelagic species often visit the grass mat community for either shelter, in search of food or for breading purpose. They include Xenomystus nigri, Gymnarchus niloticus and Channa obscura. The finfish composition in the habitat was however, dominated by Dormitator pleurops of the family Eliotridae with a total of 359 individuals. This was followed by Bostrichus africanus of the same family with 205 individuals. The least in abundance was Thysia angorgii of the family Ciclidae with 4 individuals. Endangered species of Neolebias powelli was also found among the grass mat species. The grass mat habitat was basically freshwater habitats and occurred only in zones 1 and 2 of the Creek. Brackish water or (zone 3) had no grass mat and boar just 4 species caught at its banks. Total density per zone ranged from 114 to 668 individuals $/ 1257.1 \mathrm{~cm}^{2}$, relative abundance was $8.63 \%$ to $47.65 \%$ and Margelef index 4.79 to 4.83 respectively.

Table 1: Number of individuals per zone in grass mats (Benthos) samples

March 2009 to February 2010

March 2010 to

February 2011

\begin{tabular}{|c|c|c|c|c|}
\hline FISH SPECIES & $\begin{array}{c}\text { ZONE } \\
\text { ONE }\end{array}$ & $\begin{array}{l}\text { ZONE } \\
\text { TWO }\end{array}$ & $\begin{array}{l}\text { ZONE } \\
\text { THREE }\end{array}$ & $\begin{array}{l}\text { TOTA } \\
\mathbf{L}\end{array}$ \\
\hline Heterotis niloticus (jauvinile) & 65 & - & - & 65 \\
\hline Calarmoichthys calabarisene ( uvenile) & - & 2 & - & 2 \\
\hline Channa obscura ( uvenile) & 116 & 64 & - & 180 \\
\hline Polycentropsis abrevaiate & 21 & 38 & - & 59 \\
\hline Clarias sp ( uvenile) & 1 & 4 & - & 5 \\
\hline Heterobranchus longifilis ( uvenile) & 1 & 2 & - & 3 \\
\hline Aphyosemion gardener & 73 & 30 & - & 103 \\
\hline A. calliurim & 27 & 31 & - & 58 \\
\hline Epiplatys grahami & 35 & 11 & - & 46 \\
\hline E. sexfaciatus & 16 & 10 & - & 26 \\
\hline Aplochielichthys macrophtalmus & 18 & 22 & - & 40 \\
\hline Nannocharax niloticus & 77 & 38 & - & 115 \\
\hline Bostrichus africana & 10 & 16 & 22 & 48 \\
\hline Eleotris sengalensis & 16 & 21 & 25 & 62 \\
\hline Karibia kribensis & 24 & 36 & - & 60 \\
\hline Dormitator pleurops & 34 & 58 & - & 92 \\
\hline Thysia ansorgii & 4 & 15 & - & 19 \\
\hline Neolebias powelli. & 50 & 31 & - & 81 \\
\hline Gobius sp. & 3 & 9 & 5 & 17 \\
\hline Paradistichondus dimdiatus & 16 & 56 & - & 72 \\
\hline
\end{tabular}

\begin{tabular}{rrrr}
\hline ZONE & ZONE & ZONE & \multicolumn{2}{c}{ TOTA } \\
ONE & TWO & THREE & L \\
\hline 37 & - & - & 37 \\
2 & 3 & - & 5 \\
109 & 58 & - & 167 \\
18 & 25 & - & 43 \\
11 & 9 & - & 20 \\
6 & 3 & - & 9 \\
33 & 26 & - & 59 \\
44 & 24 & - & 68 \\
53 & 34 & - & 87 \\
62 & 48 & - & 110 \\
16 & 18 & - & 34 \\
21 & 19 & - & 40 \\
8 & 77 & 120 & 205 \\
6 & 3 & 8 & 17 \\
59 & 69 & - & 128 \\
175 & 184 & - & 359 \\
9 & 16 & - & 25 \\
4 & - & - & 4 \\
4 & 7 & 2 & 13 \\
- & - & - & -
\end{tabular}


Syngnathus sp.

Echelus sp.

Pantodon bucholzi

Hemichromis bimaculatus

Marcrousenius thuysi

Mastaceblus loennbergi

Total Species

Total

Mean Total Density (Indiv./1257.1 $\mathrm{cm}^{2}$ )

Relative Abundance (\%)

Margelef Index of Species Richness

\begin{tabular}{rrrr}
- & - & 50 & 50 \\
6 & 4 & - & 10 \\
23 & 65 & - & 88 \\
25 & 57 & - & 82 \\
- & - & 12 & 12 \\
7 & - & - & 7 \\
$\mathbf{2 3}$ & $\mathbf{2 2}$ & $\mathbf{5}$ & $\mathbf{5 0}$ \\
$\mathbf{6 6 8}$ & $\mathbf{6 2 0}$ & $\mathbf{1 1 4}$ & $\mathbf{1 4 0 2}$ \\
$\mathbf{2 9 . 0 4}$ & $\mathbf{2 8 . 1 8}$ & $\mathbf{2 2 . 8 2}$ & $\mathbf{2 8 . 0 4}$ \\
$\mathbf{4 7 . 6 5}$ & $\mathbf{4 4 . 2 2}$ & $\mathbf{8 . 1 3}$ & $\mathbf{1 0 0}$ \\
$\mathbf{2 2 . 8 5}$ & $\mathbf{2 1 . 8 4}$ & $\mathbf{4 . 7 9}$ & \\
\hline
\end{tabular}

23.

$\begin{array}{rrrr}- & - & 151 & 151 \\ 18 & 13 & 31 & 62 \\ 8 & 16 & - & 24 \\ 16 & 23 & - & 39 \\ 40 & 33 & - & 73 \\ 4 & - & - & 4 \\ \mathbf{2 4} & \mathbf{2 1} & \mathbf{5} & \mathbf{5 0} \\ \mathbf{7 6 3} & \mathbf{7 0 8} & \mathbf{3 1 2} & \mathbf{1 7 9 0} \\ \mathbf{3 1 . 7 9} & \mathbf{3 3 . 7 1} & \mathbf{6 2 . 4} & \mathbf{3 5 . 8} \\ \mathbf{4 2 . 6 3} & \mathbf{3 9 . 5 5} & \mathbf{1 7 . 4 3} & \mathbf{1 0 0} \\ \mathbf{2 3 . 8 5} & \mathbf{2 8 . 8 5} & \mathbf{4 . 8 3} & \\ & & & \end{array}$

\section{Discussion}

Several factors affect the quality of natural occurring water. They include anthropogenic and natural factors. Changes in water quality resulting from these factors are usually manifested in various physical and chemical attributes. Variations in temperature within $25^{\circ} \mathrm{C}$ and $43^{\circ} \mathrm{C}$ during the period of this study was within temperature range of most tropical waters (Welcome 2001, Erondu and Chindah (1986), Zabby and Hart (2005). Mean temperature range of $25.6^{\circ} \mathrm{C}+1.1$ to $30.8^{\circ} \mathrm{C}+2.5$ were also within the range observed in similar inland waters of the Niger Delta. The observed depth profile range of the Creek revealed the creek was shallow. Mean depth variations per station range of $110 \mathrm{~cm}+11.3$ to $479 \mathrm{~cm}+160$ was quite low and was attributed to silting and debris deposits from both adjoining swamps and forest drains.

The increasing depth profile upstream - downstream shows that most suspended particulate matter especially heavier ones tend to settle upstream while lighter ones go downstream.

Flow rate range of $2.5 \mathrm{~cm} / \mathrm{s}$ in station 5 to $15 \mathrm{~cm} / \mathrm{s}$ in stations 1 and 2 was in agreement with observations of Adeniyi (1986) and Edoghotu (1998) of tidal creeks of the Niger Delta. Mean speed range within the study period of $4.33 \mathrm{~cm} / \mathrm{s}+0.7$ to $7.0 \mathrm{~cm} / \mathrm{s}$ where however relatively lower than Sikoki and Zabby (2006)

Secchi disc measurements for transparency which varied between $25 \mathrm{~cm}$ to $900 \mathrm{~cm}$ depict high level of suspended matter that shade light penetration. This was evident in the mean transparency per station which ranged from $34.89 \mathrm{~cm}+2.67$ and $265.00 \mathrm{~cm}+58.87$, and will have negative impact on primary production, especially in upstream or freshwater region. $\mathrm{pH}$ value range of 5.0 to 7.7 during the period of study was a mark of fluctuation between acidic and alkaline condition. This was further demonstrated in the sample mean values of $8.9+1.3$ and $12.7+0.4$.

However, the dissolved oxygen (DO) levels below $5.0 \mathrm{mg} / \mathrm{l}$ were critical for the survival of aquatic organisms such as fish. Values observed in this study ranged from $1.7 \mathrm{mg} / \mathrm{l}$ in the some freshwater stations during dry season to $13 \mathrm{mg} / \mathrm{l}$ in the brackish water zone. Mean values ranged from $2.9 \mathrm{mg} / \mathrm{l}+0.84$ to $8.20 \mathrm{mg} / \mathrm{l}+$ 4.1.

The grass mat finfish community is a rear and sensitively community in grass mat habitat. Its composition is usually of few species relative to that of open waters or pelagic environment. That of Kugbo Creek had 3192 individuals in 26 species and 14 families. Inspite of this relatively low diversity, the family Eliotaidae with two species was highest in abundance Domitator pleurops with 359 individuals dominated the grass mat finfish assemblage while Bostrichus africana with 205 individuals seconded. Though their sizes ranged from $0.5 \mathrm{~cm}$ to $7 \mathrm{~cm}$ in length and $0.1 \mathrm{~g}$ to $25 \mathrm{~g}$ in weight, most fish caught in sample were matured adults of reproductive sizes. However, the fish samples obtained during this study were a mixture of adults and juveniles of some larger species such as Channa obscura, Calamoichthys calabaricus and Heterobranchus longifilis. Fish density in this habitat ranged from 12 individuals in wet season to 301 individuals per $1,257.1 \mathrm{~cm}^{2}$ in the dry months. This observation was attributed to migration from the main shore to the adjacent inland swamps and flood plains during the rainy season and return to the main stream at the end of rainy season when the water recedes. Both relative abundance and Margelef indices value depicts few species dominance among zones 1 and 2. Larger carnivores of the Creek system depend on organisms of this habit for food as some have been isolated in their diet. The habitats' ability to shelter endangered species like Neolebia powelli makes it more important and interesting; therefore further necessitate its protection. Unfortunately, it had not been protected at anytime and is prone to destruction of navigator, fishers, developers and industrialists as already done in many quarters.

It was observed in the study that the grass mat cover which predominantly of the fresh water stretch upstream, decreased downstream until it was completely absent in the Brackish water zone 3. Thus, fish density decreased from fresh water zone 1( ) habitat was more concentrated in freshwater zones and also, decreasing from upstream freshwater downstream (Brackish water), where only 4 fish species were caught as seen in tables 1 and 2. 


\section{Recommendations}

1. Due to the sensitive nature of this habitat, it is easily distorted or completely destroyed in the event of pollution or anthropogenic activities. This should be checked by restricting both anthropogenic activities such as industrial and frequent fishing from grass mat habitats.

2. Fishing and developmental activities that involves removal, distortion or complete destruction of grasses of the habitat should be checked.

3. Use of poisonous chemicals and biological poison as herbicide or method of fishing should be prohibited as such applications are likely to reduce or eliminate resident grasses thereby completely destroying the habitat.

\section{References}

[1]. Adeniyi I.F. (1786). The ecology of Bonny estuary: Chemical composition of Rivers and Creeks, paper presentation on man and biosphere workshop of wetlands of Port Harcourt, Nigeria.

[2]. American Purblic Health Association, APHA (1976). American Water Works Association and Water Pollution Control Federation. Standard method of the examination of water/waste waste water. $14^{\text {th }}$ Edition. APHA, AWWA and WPCF, New York.

[3]. Anderson I. (2005) Niger River basin: A Vision for Sustainable Development Pp. 1-131, The World Bank, 2005.

[4]. Edoghotu, A.J. (1989). The ecological quotient of point source pollution in Okpoka Creek off P Harcourt. Nlgeria. M,Sc.Thesis. Department of Marine biology, Rivers State University of Science and Technology, Port Harcourt. Nigeria.

[5]. Erondu, E.S. and A.C. Chindah (1986). Physico. Chemical and phytoplankton changes in a tidal freshwater station of the New Calabar River, Southern Nigeria, Envi and Ecol. 9(3):561 - 570.

[6]. Nwilo, P. C. and Olusegun T. B. (2007). Impacts and Management of oil spill pollution along the Nigerian Coastal Areas. International Federation of Surveyors. Retrieved May, $20^{\text {th }} 2007$.

[7]. Sikoki, F.D. and N. Zabbey (2006). Aspects of fisheries of the middle of Imo River, Niger Delta, Nigeria, Environment and Ecology 24(2): 309-3

[8]. Welcome, R.L. (2001). Inland fisheries, ecology and management, Oxford U.K. Blackwell Science.

[9]. World Wildlife Fund (2006) Fishing on the Niger River. Retrieved May 10 2007 from hppt:/www.panda.org/news facts/multimedia/video/index.cfm?uNewsID=61121

[10]. Zabbey,.N and A. I. Hart ( 2005). Influence of some Physico-chemical parameters on the composition and distribution of benthic fauna in Woji Ccreek, Niger Delta, Nigeria. 